\title{
Penerapan Algoritma Boyer-Moore Dalam Perpustakaan Virtual SMK Muhammadiyah 1 Samarinda Sebagai Pendukung Pembelajaran Daring
}

\author{
Bartolomius Harpad ${ }^{1}$, Salmon ${ }^{2}$ \\ STMIK Widya Cipta Dharma ${ }^{1,2}$ \\ Jl. M. Yamin No.25, Samarinda \\ Sur-el : harpad@wicida.ac.id', salmon@wicida.ac.id ${ }^{2}$
}

\begin{abstract}
The existence of a library can be a historical chain for the past, a root for living in the present and a guide for stepping into the future. The library of SMK Muhammadiyah 1 Samarinda is a source of student knowledge that can improve the quality of student knowledge. Most of the school libraries in Samarinda, book searches are still not computerized, manual searches or searches cause operational activities to be ineffective and run slowly. Therefore, to overcome this problem, a virtual search system was created by implementing the Boyer-Moore algorithm. The system development tool uses flowchart, and the development method uses waterfall with the stages of development being analysis, design, coding, testing and maintenance. Data collection techniques consist of secondary data obtained by studying literature studies in the form of writings or documents, primary data comes from the location of the study directly, besides that data collection through observation is also carried out, namely direct observation of how the system works, system problems, system input data, existing processes and system outputs.
\end{abstract}

Keywords: Boyer-Moore algorithm, online, library.

\begin{abstract}
Abstrak: Keberadaan perpustakaan dapat menjadi rantai sejarah bagi masa lalu, akar bagi hidup dimasa sekarang ini dan pembimbing untuk melangkah ke masa depan. Perpustakaan SMK Muhammadiyah 1 Samarinda merupakan sumber pengetahuan siswa yang dapat meningkatkan kualitas pengetahuan siswa. Sebagian besar perpustakaan sekolah di samarinda penelusuran buku masih belum terkomputerisasi, pencarian atau penelusuran manual menyebabkan kegiatan operasional tidak efektif dan berjalan lambat. Untuk mengatasi masalah tersebut dibuat sistem penelusuran secara virtual dengan mengimplementasikan algoritma Boyer-Moore. Alat bantu pengembangan sistemnya menggunakan flowchat, dan metode pengembangan menggunakan waterfall dengan tahapan pengembangannya adalah analisis, desain, coding dan pengujian. Teknik pengumpulan data terdiri data sekunder diperoleh dengan mempelajari studi literatur yang berupa tulisan atau dokumen, data primer berasal dari lokasi pengkajian secara langsung, selain itu pengumpulan data melalui observasi juga dilakukan, yaitu pengamatan langsung tentang cara kerja sistem, permasalahan sistem, data inputan sistem, proses dan keluaran sistem yang ada.
\end{abstract}

Kata kunci: Webqual 4.0, E-S Qual, Crowdfunding, Website quality

\section{PENDAHULUAN}

Fungsi dan wujud dari perpustakaan terus berkembang seiring dengan perkembangan peradaban manusia dari mulai zaman batu, ketika manusia menyimpan sumber pengetahuan pada lempengan batu sampai kini berada pada awal millenium ketiga yang mana sumber pengetahuan sudah banyak yang disimpan dalam bentuk digital yaitu format dari sumber pengetahuan yang dapat dimengerti oleh komputer, apalagi dengan adanya internet perpustakaan menjadi lebih fungsional. Peranan perpustakaan harus mampu menunjukkan identitasnya sebagai penyedia informasi yang 
representative dalam arti yang seluas-luasnya [1].

Masa Pandemi Covid-19 mengubah semua kegiatan belajar-mengajar di sekolah menjadi pembelajaran daring. Arahan Pemerintah yang melarang siswa untuk datang ke sekolah membuat siswa susah untuk mendapatkan bukubuku pelajaran. Buku-buku cetak yang biasanya disediakan gratis oleh perpustakaan sekolah di setiap mata pelajaran tidak dapat lagi diperolah siswa di sistem pembelajaran daring ini. Adapun tujuan diselenggarakannya perpustakaan adalah untuk mendukung, memperlancar serta mempertinggi kualitas pelaksanaan program kegiatan perguruan tinggi melalui pelayanan informasi yang meliputi lima aspek yaitu pengumpulan informasi, pelestarian informasi, pengolahan informasi, pemanfaatan informasi dan penyebarluasan informasi [1].

Sistem penelusuran merupakan salah satu bagian dari pengolahan dan pemanfaatan informasi, dibeberapa sekolah khususnya di SMK Muhammadiyah 1 Samarinda, penelusuran buku masih belum terkomputerisasi, pencarian atau penelusuran manual menyebabkan kegiatan operasional tidak efektif dan berjalan lambat, dari permasalahan di sekolah tersebut diperlukan suatu sistem yang dapat memecahkan permasalahan sehingga dapat mempermudah dalam pembelajaran daring dan pengunjung perpustakaan [2].

Sistem penelusuran yang akan dibangun memerlukan algoritma pencarian string. Algoritma Boyer-Moore ini dianggap sebagai algoritma yang paling efisien dalam implementasi penelusuran buku pada perpustakaan secara virtual.

\section{METODOLOGI PENELITIAN}

Metodologi penelitian ini berisikan teori yang berkaitan dengan model pengembangan waterfall dengan menggunakan algoritma Boyer-Moore.

\subsection{Model Waterfall}

Model waterfall adalah model klasik yang bersifat sistematis, berurutan dalam membangun software. Nama model ini sebenarnya adalah "Linear Sequential Model". Model ini sering disebut juga dengan "classic life cycle" atau metode waterfall. Model ini termasuk ke dalam model generic pada rekayasa perangkat lunak dan pertama kali diperkenalkan oleh Winston Royce sekitar tahun 1970 sehingga sering dianggap kuno, tetapi merupakan model yang paling banyak dipakai dalam Software Engineering (SE). Model ini melakukan pendekatan secara sistematis dan berurutan. Disebut dengan waterfall karena tahap demi tahap yang dilalui harus menunggu selesainya tahap sebelumnya dan berjalan berurutan [3].

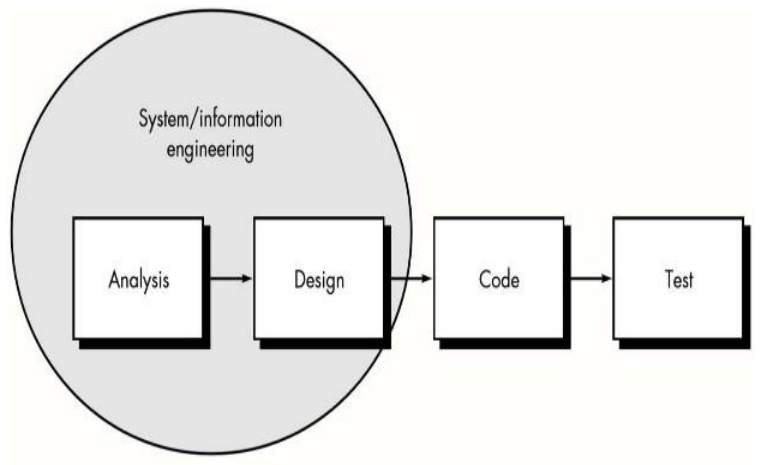

Gambar. 1 Alur Penelitian 
Fase-fase dalam Waterfall Model sebagai berikut:

1. Analysis, Sebelum memulai pekerjaan yang bersifat teknis, analisis sangat diperlukan untuk memahami dan mencapai tujuan yang ingin dicapai. Adapun analisi yaitu meliputi inisialisasi proyek, seperti menganalisis permasalahan yang dihadapi dan mengumpulkan data-data yang diperlukan, serta membantu mendefinisikan fitur dan fungsi software. Pengumpulan data-data tambahan bisa juga diambil dari jurnal, artikel, dan internet.

2. Design. Tahapan ini adalah tahap perancangan dan permodelan arsitektur sistem yang berfokus pada perancangan struktur data, arsitektur software, tampilan interface, dan algoritma program. Tujuannya untuk lebih memahami gambaran besar dari apa yang akan dikerjakan.

3. Code. Tahapan Code ini merupakan proses penerjemahan bentuk desain menjadi kode atau bentuk/bahasa yang dapat dibaca oleh mesin.

4. Test. Setelah pengkodean selesai, dilakukan pengujian terhadap sistem dan juga kode yang sudah dibuat. Tujuannya untuk menemukan kesalahan yang mungkin terjadi untuk nantinya diperbaiki.

Setiap fase dilakukan secara berurutan mulai dari langkah pertama sampai langkah terakhir, setiap langkah yang telah selesai dikerjakan harus dilakukan pengkajian ulang, tertera dalam alur penelitian pada Gambar 1 .

\subsection{Algoritma Boyer Moore}

Algoritma pencarian string Boyer Moore merupakan algoritma pencarian string yang paling efisien dalam aplikasi sehari hari. Algoritma tersebut dikembangkan oleh Bob Boyer dan J Strother Moore pada tahun 1977. Pada proses pencarian string, algoritma Boyer Moore membaca karakter-karakter dari pattern dari kanan ke kiri. Dalam kasus dimana jumlah karakter pada pattern lebih sedikit daripada jumlah karakter pada teks maka algoritma tersebut menggunakan 2 buah fungsi precomputed. 2 buah fungsi pengubah ini disebut good-suffix shift. Aturan pada good-suffix shift bertujuan untuk menangani kasus dimana terdapat pengulangan karakter pada pattern. Algoritma Boyer Moore mempunyai empat konsep dasar di dalam proses pencarian string, yaitu :

\section{Preprocessing}

2. Right-to-left-scan

3. Bad-character-rule

\section{Good-suffix-rule}

Precomputation dari algoritma Boyer Moore terdiri dari bad-character preprocessing dan good-suffix preprocessing. Prinsip dasar yang pertama dari algoritma Boyer-Moore adalah melakukan perbandingan antara pattern yang dicari dengan teks. Perbandingan pattern dengan teks dilakukan dari arah kanan ke kiri. Perbandingan dimulai dengan membandingkan antara karakter paling kanan dari pattern dengan teks. Jika terjadi kecocokkan, maka perbandingan akan dilanjutkan dengan karakter yang di sebelah kiri dari yang dibandingkan sampai ke karakter pertama dari pattern. Jika 
terjadi ketidakcocokkan maka akan dilakukan pergeseran yang ditentukan oleh 2 fungsi pergeseran yaitu bad character shift dan good suffix shift. Aturan dari bad character shift dibutuhkan untuk menghindari pengulangan perbandingan yang gagal dari suatu karakter dalam teks dengan pattern. Aturan dari good suffix shift dibutuhkan untuk menangani kasus yang di dalamnya terdapat pengulangan karaker pada pattern [4].

Algoritma Boyer-Moore dianggap sebagai algoritma pencocokan string yang paling efisien pada penggunaan biasa karena algoritma BoyerMoore telah menjadi standar untuk pencarian string menurut Udi dkk. Berbagai versi algoritma ini digunakan dalam teks editor untuk perintah pencarian dan pergantian (find and replace) Algoritma pencocokan string Boyer-Moore didasarkan atas dua teknik [5]:

1. Teknik looking-glass, menemukan pattern di dalam teks dengan menggerakan pattern mundur dimulai dari akhir teks.

2. Teknik character-jump, pergeseran karakter yang dilakukan saat terjadi ketidakcocokan.

Karakteristik utama algoritma Boyer-Moore :

1. Melakukan perbandingan dari kanan ke kiri.

2. Fase persiapan/prepocessing membutuhkan kompleksitas waktu $\mathrm{O}(\mathrm{m}+\sigma)$

3. Fase pencarian : kompleksitas waktunya $\mathrm{O}$ (mn)

4. Pada kasus terburuk, sebanyak 3n karakter teks yang dibandingkan untuk pattern yang tak berulang.

5. Kasus terbaik $\mathrm{O}(\mathrm{n} / \mathrm{m})$

Menurut Edward Rompah pada artikelnya yang membahas tentang algoritma Boyer-
Moore, algoritma Boyer-Moore dipublikasikan oleh Robert S. Boyer, dan J. Strother Moore pada tahun 1977. Ide utama dari algoritma ini adalah dengan melakukan pencocokan dari paling kanan string yang dicari. Dengan menggunakan algoritma ini, secara rata-rata proses pencarian akan lebih cepat dibandingkan dengan proses pencarian lainnya. Ide dibalik algoritma ini adalah bahwa dengan memulai pencocokan karakter dari kanan, dan bukan dari kiri, maka akan lebih banyak informasi yang didapat [6].

\subsection{Perpustakaan}

Perpustakaan adalah institusi yang menyediakan koleksi bahan pustaka tertulis, tercetak dan terekam sebagai pusat informasi yang diatur menurut sistem aturan dan didayagunakan untuk keperluan pendidikan, penelitian, serta rekreasi intelektual bagi masyarakat. Perpustakaan berperan melakukan layanan informasi literal kepada masyarakat [7].

\subsection{Flowchart}

Definisi dari diagram Alir dan flowchart adalah diagram yang menggambarkan urutan logika dari suatu prosedur pemecahan masalah. Tujuan utama dari penggunaan flowchart adalah untuk menggambarkan suatu tahapan penyelesaian masalah secara sederhana, terurai, rapi, dan jelas dengan menggunakkan simbol standar. Proses pengembangan Flowchart terdapat dua jenis metode, yaitu conceptual flowchart dan detail flowchart. Conceptual flowchart menggambarkan tentang alur dari suatu pemecahan masalah secara global, 
sedangkan detail flowchart mengambarkan pemecahan secara rinci [8].

\subsection{Dalam Jaringan (Daring)}

Pembelajaran daring atau yang dikenal dengan istilah E-learning merupakan pembelajaran yang memanfaatkan teknologi. Menurut Dimyati menjelaskan bahwa pembelajaran daring atau yang dikenal dengan istilah elearning merupakan bentuk pemanfaatan teknologi dalam mendukung proses belajar mengajar jarak jauh. Hal ini meningkat perubahan gaya belajar yang semakin pesat [9].

\section{HASIL DAN PEMBAHASAN}

\subsection{Skematik Sistem}

Langkah langkah yang harus diikuti oleh seorang user atau pengguna antara lain :

1. Pengguna atau seorang user menginputkan kata yang dicari

2. Pengguna menginputkan judul buku atau pengarang buku yang akan di cari, atau bisa kedua - duanya dalam aplikasi ini.

3. Pencarian akan dilakukan dari record pertama pada judul atau nama pengarang.

4. Lakukan perbandingkan, apakah pencarian dilakukan berdasarkan judul, jika iya lakukan, jika tidak lakukan perbandingkan berdasarkan pengarang.

5. Perbandingan selanjutnya, apakah kata yang dicari ketemu, jika ya simpan didalam katalog, dan jika tidak masuk keperbandingan berdasarkan pengarang.

6. Apakah pencarian yang dilakukan berdasarkan pengarang, jika iya lakukan, dan simpan dalam katalog, jika tidak lanjutkan ke record selanjutnya.

7. Dari proses record selanjutnya, akan dilakukan perbandingan, apakah record sudah mencapai EOF, jika tidak akan kembali ke perbandingan berdasarkan judul, dan jika record sudah mencapai EOF, akan dilakukan perbandingan apakah data buku dalam katalog.

8. Perbandingan selanjutnya, apakah data dalam katalog ada atau ditemukan, jika tidak tampilkan pesan kata tidak ditemukan dalam proses pencarian, jika iya tampilkan data yang ditemukan dan selesai.

\subsection{Tampilan Sistem}

Pada gambar 2 merupakan awal proses, terdapat dua pilihan masuk sebagai pengunjung atau masuk sebagai admin, apabila masuk ke sistem wajib memasukkan terlebih dahulu username dan password, jadi langsung bisa melihat daftar buku perpustakaan.

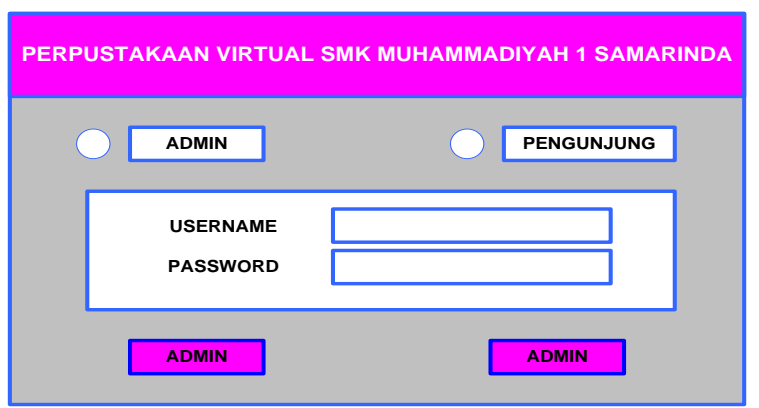

Gambar 2. Menu Login

Pada gambar 3, merupakan tampilan dari daftar buku untuk pengunjung, pada rancangan ini, terdapat tombol data buku, tombol klasifikasi buku, tombol cari buku, tombol cetak data buku dan tombol Kembali. 


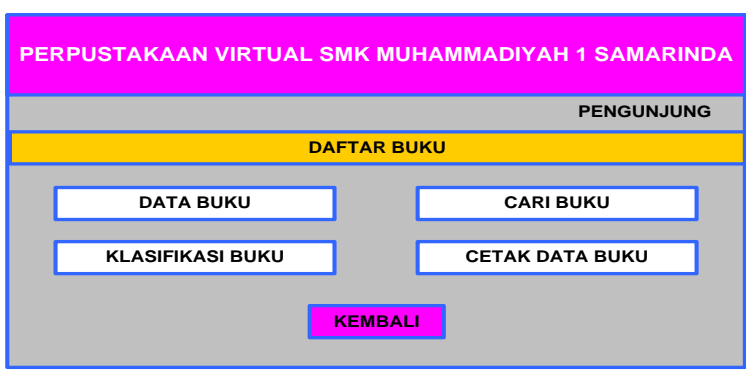

Gambar 3. Tampilan Daftar Buku

Pada gambar 4, halaman data buku terdapat empat tombol, yaitu tombol baru, berfungsi untuk menambahkan data buku, kemudian tombol simpan, berfungsi untuk menyimpan data yang sudah diinputkan. Tombol cari, tombol ini kalau di klik akan secara otomatis masuk ke form pencarian yang sudah disediakan. Kemudian tombol keluar, berfungsi untuk kembali ke menu utama.

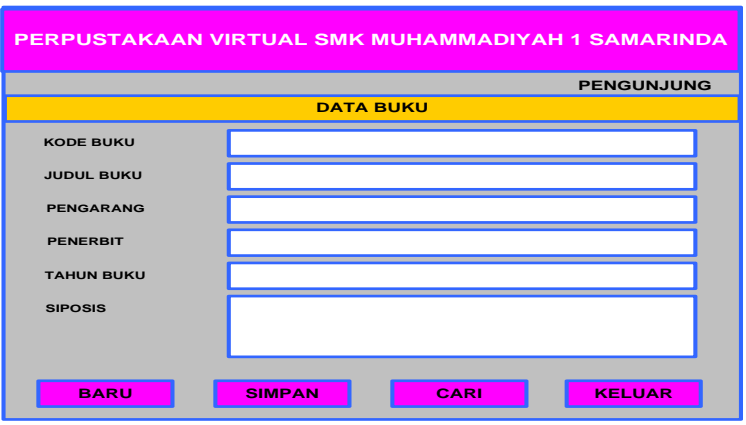

Gambar 4. Tampilan Data Buku

Pada gambar 5, halaman ini merupakan menu yang digunakan untuk pencarian, pada form ini, seorang pengguna akan dapat menandai kriteria yang ada dalam form ini, setelah seorang pengguna menginputkan kata yang ada dalam list box, dan apabila pengguna lupa untuk menandai kriteria tersebut, maka akan muncul pesan message box yang memberi tahu bahwa proses menandai belum dilakukan. Dalam form ini terdapat tiga tombol utama, yaitu tombol cari untuk mencari kata yang telah diinputkan.
Kemudian tombol bersih, berfungsi untuk membersihkan kata yang ada dalam list box apabila kita akan memasukkan kata yang baru. Dan yang ketiga adalah tombol kembali, berfungsi untuk kembali ke form теnи utama.

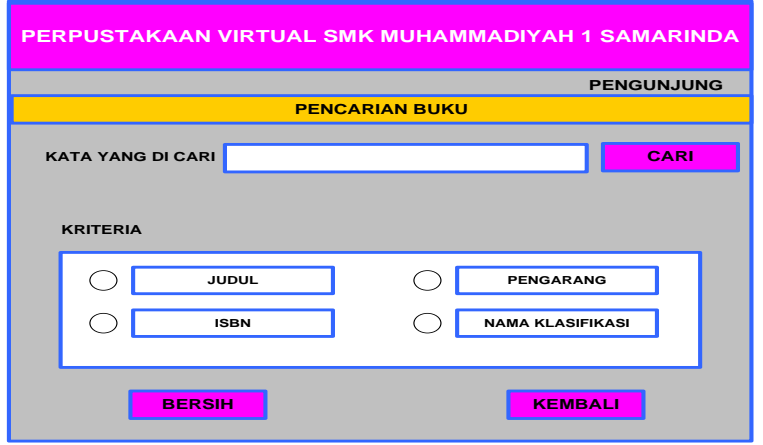

Gambar 5. Tampilan Pencarian Buku

\section{KESIMPULAN}

Dari hasil penelitian dan pembahasan yang diperoleh pada SMK Muhammadiyah 1 Samarinda, maka kesimpulan yang diperoleh adalah Sistem penelusuran katalog perpustakaan sekolah secara virtual dengan mengimplementasikan Algoritma Boyer-Moore dapat membantu meringankan kerja petugas atau admin dalam memberi laporan jumlah buku yang tersedia diperpustakaan, dan juga dalam melayani pengunjung yang ingin mengetahui koleksi buku dan meminjam buku di $\begin{array}{llll}\text { perpustakaan } & \text { SMK Muhammadiyah } 1\end{array}$ Samarinda.

\section{UCAPAN TERIMA KASIH}

Judul Dibiayai oleh Direktorat Riset dan Pengabdian Masyarakat Direktorat Jenderal Penguatan Riset dan Pengembangan Kementerian Riset, Teknologi, dan Pendidikan Tinggi sesuai Dengan Kontrak Penelitian Tahun Anggaran 2021. 


\section{DAFTAR PUSTAKA}

[1] Putera, A. R., \& Ibrahim, M., Rancang Bangun Sistem Informasi Peminjaman dan Pengembalian Buku Perpustakaan SMP Negeri 1 Madiun. Doubleclick: Journal of Computer and Information Technology, 1(2), 57-61. 2018.

[2] Pratiwi, D., Hartini, S., \& Marlina, S., Rancang Bangun Sistem Informasi Perpustakaan Pada Sekolah SMK Yadika 13 Tambun Utara Berbasis WEB. ParadigmaJurnal Komputer dan Informatika, 20(1), 53-58. 2018.

[3] Pressman R. Software Engineering: A Practitioner's Approach Seventh Edition. New York: McGraw Hill. 2010.

[4] Aulia, R., Analisis Algoritma Knuth Morris Pratt dan Algoritma Boyer Moore dalam Proses Pencarian String. Makalah If 2251 Strategi Algoritmik, pp. 1-5. 2008.

[5] Fernando, Hary., "Perbandingan dan pengujian beberapa algoritma pencocokan string." Makalah IF2251, pp.1-7. 2009.

[6] Sagita, Vina, And Maria Irmina Prasetiyowati., "Studi Perbandingan Implementasi Algoritma Boyer- Moore, Turbo Boyer-Moore, Dan Tuned BoyerMoore Dalam Pencarian String." Ultimatics 5.1, pp.31-37. 2013.

[7] Pertiwi, Dini Hari., "Desain dan Implementasi Sistem Informasi Perpustakaan Berbasis WEB dengan MVC (Model View Controler). " Jurnal Teknologi Informatika (TEKNOMATIKA) 1, pp. 1-23. 2011

[8] Sutedjo, Budi Dan An, Michael., "Algoritma Dan Teknik Pemrograman Konsep, Implementasi, Dan Aplikasi“. Yogyakarta: Andi. 2002

[9] Dimyati, Mudjiono., Belajar Dan Pembelajaran. Jakarta: Rineka Cipta. 2015. 